\title{
Effect of Traditional Market Liquid Organic Fertilizer on Production and Nutritional Quality of Setaria Splendida Stapf Defoliation
}

\author{
Eko Hendarto $^{1^{*}}$, Harwanto ${ }^{2}$, Bahrun $^{3}$, Nur Hidayat ${ }^{4}$ and Adi Fathul Qohar ${ }^{5}$
}

*Corresponding author

Eko Hendarto, Faculty of Animal Science, Jenderal Soedirman University,

1,2,3,4,5 Faculty of Animal Science, Jenderal Soedirman University, Purwokerto - Indonesia.

Purwokerto - Indonesia

Submitted: 30 Apr 2020; Accepted: 15 Jun 2020; Published: 25 Jun 2020

\begin{abstract}
The amount of organic waste from traditional markets is high in number and has the potential to pollute the environment. The waste is generally made into compost, but through simple technology liquid organic fertilizer can be made that can be applied to feed plants. Setaria splendida Stapf grass is one of the superior feed plants. The purpose of this study was to determine the quality of forage Setaria splendida Stapf which is fertilized with liquid organic fertilizer from traditional market waste at various harvest ages. The treatment is in the form of 3 (three) doses of liquid organic fertilizer mixed with water namely 1:1, 1:2 and 1: 3 (liquid organic fertilizer: water) and the harvest age is 35, 40 and 45 days. Repeat 3 times. The plot size is $1 \times 2$ square meters. The study design was a Complete Random Design. The variables studied were the production of fresh forages, dry matter content, crude protein content, crude fat content and crude fiber content. Data were analyzed by analysis of variance, if there is an effect followed by a regression test. The results showed that the harvest age was getting older, more fresh forage production and the nutritional quality of Setaria splendida Stapf decreased while the dose of liquid organic fertilizer was more concentrated, fresh forage production and the quality was getting better. Most fresh forage production is obtained at 45 days of harvest and 1: 1 dilution rate, while the best forage quality is obtained at a younger age (35 days) with a dose of liquid organic fertilizer at a ratio of 1: 1.
\end{abstract}

\section{Introduction}

Each region has a traditional market which in general its activities produce large amounts of organic waste and have the potential to pollute the environment. In general organic waste is made into compost which has been widely applied [1]. But with traditional market organic waste fermentation technology, liquid organic fertilizer can be made as an effort to de-diversify utilization [2]. The successful use of liquid organic fertilizer from traditional market organic waste will increase the benefits for human life, especially in the agricultural sector [3]. The negative impact of traditional market organic waste can produce tangible benefits. The advantage of using liquid organic fertilizer in agricultural activities is that the nutrients are easily absorbed by plants and are easy to use [4]. Setaria splendida Stapf is one of the superior feed plants for ruminant livestock sources favored by livestock [5].

In general, liquid fertilizer as an organic element has a low chemical content, but its nutrients are good for meeting plant needs [6]. The advantage is that if there is an excess of nutrients in the soil, plants are able to regulate their absorption [7]. This capability, according to Hendarto, et al (2018), is also found in liquid organic fertilizer from traditional market waste that is found in many places, especially in Indonesia. If it can be popular and economically beneficial, it will provide high benefits for human life [8]. According to Hendarto et al, (2011), based on the observation of traditional market organic waste, the amount can reach a very large amount potentially disrupting human life, but on the other hand the waste through processing technology can also support human life including being made into liquid organic fertilizer for crop cultivation [9].

Forage plants that produce forage, the quality is influenced by age of harvest $[10,11]$. Forage produced in the form of leaves, stems and young twigs that can be given for food [12]. In this regard, the age of harvest will determine the carrying capacity and carrying capacity of livestock [13]. Variable carrying capacity and carrying capacity can be seen from the production of fresh forages and forage quality which include dry matter content, crude fiber content, crude protein content and crude fat content [5]. In this regard, research on fresh forage production and quality from Setaria splendida Stapf grass is fertilized with liquid organic fertilizer, traditional market organic waste harvested at various plant ages.

\section{Materials and Methods}

Experimental research with Setaria splendida Stapf grass plant material fertilized with liquid organic fertilizer, traditional market organic waste harvested at various plant ages. Complete Random Design was used on 2 (two) factors, namely the dose of liquid organic fertilizer mixed with water $(1: 1,1: 2$ and $1: 3)$ and harvest age $(35$, 40 and 45 days). The treatment was repeated 3 (three) times, in a number of 27 plots measuring $1 \times 2$ square meters. Based on the tests of the quality of liquid organic fertilizer, traditional market 
wastes are relatively very low, namely nitrogen content of 0.038 percent, phosphorus content of $81.748 \mathrm{ml} /$ liter while potassium content is 0.134 percent. Applications for the use of liquid organic fertilizer, traditional market organic waste mixed with water in the study area are listed in [Table 1].

Table 1: Use of Mixed Doses of Liquid and Organic Fertilizers

\begin{tabular}{|l|l|l|l|l|l|}
\hline Num & $\begin{array}{l}\text { Treat- } \\
\text { ment } \\
\text { Code }\end{array}$ & $\begin{array}{l}\text { Liquid } \\
\text { Organic } \\
\text { Fertilizer } \\
\text { Market } \\
\text { waste }\end{array}$ & $\begin{array}{l}\text { Water } \\
\text { mixture }\end{array}$ & $\begin{array}{l}\text { The } \\
\text { amount } \\
\text { of liquid } \\
\text { fertilizer }\end{array}$ & $\begin{array}{l}\text { Extensive } \\
\text { use }\end{array}$ \\
\hline 1 & C-1 (1:1) & 0,30 liter & 0,30 liter & O,6 liter & $2 \mathrm{~m} 2$ \\
\hline 2 & C-2 (1:2) & 0,20 liter & 0,40 liter & 0,6 liter & $2 \mathrm{~m} 2$ \\
\hline 3 & C-3 (1:3) & 0,15 liter & 0,45 liter & 0,6 liter & $2 \mathrm{~m} 2$ \\
\hline
\end{tabular}

The variables studied were fresh forage production and nutritional quality which included levels of dry matter, crude fiber content, crude protein content and crude fat content. Its working procedures include tillage, planting Setaria splendida Stapf, fertilizing liquid organic fertilizer according to a predetermined dose. At the age of 35 days, 9 plots were harvested, fresh forage production was recorded, forage samples were taken about 100 grams and analyzed by a laboratory to measure their quality. This was done again at the age of 40 days and 45 days. The research activities took place on defoliation 1 and 2 . The data obtained were the average data from 2 defoliation, analyzed based on the Completely Randomized Design and the effect was continued with the regression test.

\section{Results and Discussion}

\section{Condition of Research Location}

The location of the study was in an open yard without shade. The results of land quality tests that have been carried out show that the nitrogen content is $48.15 \mathrm{ppm}$ (very high), P2O5 is available 0.28 ppm (very low) and $\mathrm{K} 2 \mathrm{O}$ is available 0.49 me percent (moderate). On the other hand, the nutrient content of liquid organic fertilizer is relatively low. Clay texture class with sand fraction as much as $23.36 \%$, dust fraction $19.5 \%$ and clay $57.14 \%$, degree of soil acidity 6.01 .

Based on land quality testing, it shows that the acidity level of the research land is in normal conditions, the soil structure and nitrogen content show good soil conditions for plant growth and forage production [14]. The Setaria splendida Stapf plant has a broad ability to grow in a variety of conditions [15]. This supports the application of the use of liquid organic fertilizer in crop cultivation.

Effect of Harvest Age and Dose of Traditional Market Liquid Organic Fertilizer on the Production of Fresh Forage Setaria splendida Stapf

Setaria splendida Stapf grass harvested at harvest intervals of 35-45 days, and fertilized with liquid organic fertilizer from traditional market waste produces an average production of $1.79 \mathrm{~kg}$ of fresh forage at 2 square meters or average per square meter of $0.895 \mathrm{~kg}=$ $8,055 \mathrm{~kg}$ per square meter per year $=80,055 \mathrm{~kg}$ per hectare per year. The amount of production was quite good in the implementation of 2 initial defoliations.

Observing the existing forage production, the application of liquid organic fertilizer from traditional market waste, besides being able to reduce the level of pollution, turned out to be beneficial for the production of feed crops especially Setaria splendida Stap grass $[16,17]$. Related to this further utilization of traditional market organic waste, can not only be utilized through composting alone (Hendarto, et al, 2018) or fresh feed (Okaraonye and Ikewuchi, 2009), but diversification through liquid organic fertilizer into one solution that can developed specifically in the cultivation of feed plants $[2,18,19]$. Although in general liquid organic fertilizers have relatively low levels of constituents, in the effort to utilize wasted natural resources and reduce the level of environmental pollution, their use needs to be socialized $[9,20,21]$.

The fresh forage production of Setaria splendida Stapf grass has increased since it was harvested at the age of 35 days to 45 days. Age 35 days the average production of $1.59 \mathrm{~kg}$ per plot ( 2 square meters), at the age of 40 days as much as $1.74 \mathrm{~kg}$ and age of 45 days as much as $2.05 \mathrm{~kg}$. The older the plant age, the more average production [17]. The highest production interval is obtained between the age of 40 days to 45 days which is $0.31 \mathrm{~kg}$. This happens because more and more plant roots so that more nutrients are absorbed by plants to produce photosynthesis by getting a lot of energy [6]. The older the age of the plant the potential for increased production is higher, but at a certain age there is a condition of decreased production due to the aging of plants and death $[21,22]$.

In the treatment of liquid organic fertilizer doses show [Table 2] the more the addition of water, the average level of fresh forage production decreases even though the decrease is not too flashy. In the 1: 1 mixture with the most concentrated liquid fertilizer conditions, the average fresh forage production was $1.83 \mathrm{~kg}$, in the 1: 2 mixture $1.82 \mathrm{~kg}$ and the most dilute liquid organic fertilizer ie $1: 3$ the average production rate was $1.71 \mathrm{~kg}$. These conditions indicate that there is more water dilution, resulting in a decrease in the average production of fresh forage grass Setaria splendida Stapf [23].

The results of the analysis of the variance showed that the treatment given had no effect $(\mathrm{P}>0.05)$ on the production of fresh forage grass of Setaria splendida Stapf. In the treatment of harvest age between 35 days to 45 days and liquid organic fertilizer from traditional market waste from concentrated to runny, does not provide the maximum conditions of each treatment [24]. However, the combination treatment of mixing liquid organic fertilizer with water at a ratio of 1: 1 with a harvest age of 45 days, has provided the highest level of fresh forage production of Setaria splendida Stapf grass which is as much as $2.2 \mathrm{~kg}$ per plot or $1.1 \mathrm{~kg}$ per square meter $=99,000$ $\mathrm{kg}$ per hectare per year.

Effect of Harvest Age and Dose of Traditional Market Liquid Organic Fertilizers on Dry Matter of Forage Setaria splendida Stapf

Harvesting of Setaria splendida Stapf shows data that the older the harvest, the level of dry matter is increasing [Table 2], while the application of liquid organic fertilizer from traditional market organic waste in cultivation shows that the more concentrated also shows the higher level of dry matter [7]. Nutrition laboratory analysis results showed the average dry material of Setaria splendida Stapf was 15.02 percent, stated in the range of 13.59 - 16.42 percent. The results achieved were 0.03 percent higher than the research of Hendarto, et al., (2019) which showed that the content of Setaria splendida Stapf dry matter was 14.99 percent. This happens because of differences in treatment, while in principle the difference does not cause a striking condition [25]. 
Table 2: Fresh Forage Production and Quality forage of *) Setaria splendida Stapf

\begin{tabular}{|l|l|l|l|l|l|}
\hline $\begin{array}{l}\text { Treat- } \\
\text { ment }\end{array}$ & $\begin{array}{l}\text { Fresh } \\
\text { Produc- } \\
\text { tion (kg) }\end{array}$ & $\begin{array}{l}\text { Dry Mat- } \\
\text { ter (\%) }\end{array}$ & $\begin{array}{l}\text { Crude } \\
\text { Protein } \\
(\% \mathrm{DM})\end{array}$ & $\begin{array}{l}\text { Crude Fat } \\
(\% \mathrm{DM})\end{array}$ & $\begin{array}{l}\text { Crude } \\
\text { Fiber } \\
(\% \mathrm{DM})\end{array}$ \\
\hline D35 L1 & $1,64 \mathrm{a})$ & $14,81 \mathrm{~b})$ & $9,36 \mathrm{c})$ & $3,28 \mathrm{~d})$ & $29,02 \mathrm{e})$ \\
\hline D35 L2 & $1,64 \mathrm{a})$ & $14,22 \mathrm{~b})$ & $9,10 \mathrm{c})$ & $3,11 \mathrm{~d})$ & $29,70 \mathrm{e})$ \\
\hline D35 L3 & $1,49 \mathrm{a})$ & $14,26 \mathrm{~b})$ & $9,25 \mathrm{c})$ & $3,36 \mathrm{~d})$ & $29,58 \mathrm{e})$ \\
\hline D40 L1 & $1,68 \mathrm{a})$ & $15,50 \mathrm{~b})$ & $8,81 \mathrm{c})$ & $3,02 \mathrm{~d})$ & $31,15 \mathrm{e})$ \\
\hline D40 L2 & $1,88 \mathrm{a})$ & $14,89 \mathrm{~b})$ & $8,31 \mathrm{c})$ & $3,58 \mathrm{~d})$ & $31,31 \mathrm{e})$ \\
\hline D40 L3 & $1,65 \mathrm{a})$ & $14,73 \mathrm{~b})$ & $7,89 \mathrm{c})$ & $3,35 \mathrm{~d})$ & $31,06 \mathrm{e})$ \\
\hline D45 L1 & $2,20 \mathrm{f})$ & $15,86 \mathrm{~b})$ & $8,26 \mathrm{c})$ & $3,46 \mathrm{~d})$ & $31,26 \mathrm{e})$ \\
\hline D45 L2 & $1,95 \mathrm{f})$ & $15,66 \mathrm{~b})$ & $8,49 \mathrm{c})$ & $3,61 \mathrm{~d})$ & $32,49 \mathrm{e})$ \\
\hline D45 L3 & $2,00 \mathrm{f})$ & $15,28 \mathrm{~b})$ & $8,01 \mathrm{c})$ & $3,53 \mathrm{~d})$ & $32,68 \mathrm{e})$ \\
\hline $\begin{array}{l}\text { AVER- } \\
\text { AGE }\end{array}$ & 1,79 & 15,02 & 8,61 & 3,37 & 30,92 \\
\hline
\end{tabular}

Note: *) Laboratory of Animal Nutrition and Food, Faculty of Animal Husbandry, UnsoeD, D (35, 40 and 45) = harvest age of 35, 40 and 45 days, $L(1,2$, and 3$)=$ mixture of liquid organic fertilizer with water in the ratio of 1: 1, 1: 2 and 1: 3 Superscript with the same letter in the same column shows no difference

[Table 2] shows that as plants age, the height of the plants increases so that the dry matter content also increases [26]. An increase in plant height causes some of the plant stems to grow older, which in turn increases the dry matter content $[12,19]$. The average content of dry matter at harvesting at 35 days is 14.43 percent and it continues to increase its dry matter content, the highest at 45 days of harvest, as much as 15.6 percent. The addition of dry matter content with a 5-day harvest interval, the highest between 35 days of harvest to 40 days of harvest is 0.61 percent, while for older harvests up to 45 days increased by 0.56 percent. That is because between the harvest age of 40 days to 45 days there is a decrease in the news of dry matter, although on a small difference.

[Table 2] shows that the more liquid aqueous organic fertilizer is given, the lower the level of dry forage. A mixture of liquid organic fertilizer traditional market waste with 1: 1 water produces an average level of dry matter forage Setaria splendida Stapf of 15.39 percent, decreasing with a mixture of more water to $1: 3$, the dry matter content of 14.76 percent. Nutrient content of liquid organic fertilizer in general is low which causes the response in plants to also be less, then the energy produced by plants is also low so that the levels of dry matter forage from plants are also low [13,27]. The use of liquid organic fertilizer with nutrient levels that are ready to be absorbed by plants, it is possible to give a response to the plant since it is given, but plants will respond after the plants are older than more than 35 days [24].

Based on the results of the analysis of variance showed that the treatment given did not have an impact on the levels of dry matter forage of the Setaria splendida Stapf plant. Although the older the age of defoliation, the more dry matter content and the more concentrated liquid organic fertilizer, the higher the dry matter content, but the interaction had no effect $(\mathrm{P}>0.05)$. Setaria splendida Stapf which is harvested at 45 days and fertilized with liquid organic fertilizer mixed with water at a ratio of 1: 1 has provided levels of dry matter that can be accounted for by 15.86 percent which basically can increase the production of dry matter forage Setaria splendida Stapf and increase capacity in livestock.

Effect of Harvest Age and Dose of Traditional Market Liquid Organic Fertilizer on Crude Protein Levels of Setaria splendida Stapf

Forage grass Setaria splendida Stapf as a tropical forage plant has crude protein content at an average of 8.61 percent due to various treatments of harvest age and the dose of traditional market liquid organic fertilizer [28][Table 2]. Fitriana, et al. (2017) states that the crude protein content of Setaria splendida Stapf grass is generally around 8.82 percent of the dry matter content, while the study of Hendarto, et al. (2019) on the same grass the crude protein content is 5.48 percent $[5,25]$. The nitrogen content of traditional market liquid organic fertilizer wastes contributes to existing results [4]. Although nitrogen nutrient content in organic fertilizers is low, it has supported plant growth and production including protein content from forage $[27,29]$. The value or amount of protein found in forage is highly expected in the preparation of rations [30].

Associated with the results in [Table 2] which shows the treatment that produces the highest crude protein content is grass harvested at the age of 35 days and given liquid organic fertilizer traditional market waste mixed with water with a ratio of 1 : 1 that is 9.36 percent, while the lowest crude protein content at harvesting the age of 45 days and given liquid organic fertilizer traditional market waste mixed with water with a ratio of $1: 3$ which is 8.01 percent. These conditions indicate that the age of harvesting older produce lower crude forage protein levels, according to the opinion of Tudsri, et al. (2002) that the age of harvest affects the crude protein content of the forage. The nitrogen content of fertilizer also has an impact on the crude protein content of the Setaria splendida Stapf becomes lower at higher dilution rates [14,20,31,32]. Forage protein levels, it becomes important as a supplier of feed ingredients for livestock [28].

The results of the analysis of variance that the existing treatment did not show a difference $(\mathrm{P}>0.05)$ levels of crude protein for Setaria splendida Stapf, so that the treatment could be applied. Factors that need to be considered are related to the quality of liquid organic fertilizer so that the level of dilution should be taken into consideration so that the quality of the forage produced is in line with expectations to maintain livestock productivity [33]. Comparison of liquid organic fertilizer with water at 1: 1 is the recommended dosage, while for age it is easier to consider because the older the plant, the quality of the forage is increasingly reduced [31].

Effect of Harvest Age and Dose of Traditional Market Liquid Organic Fertilizers on Crude Fat Levels of Setaria splendida Stapf

The phenomenon of crude fat content of Setaria splendida Stapf grass in [Table 2] shows that the average crude fat content of 3.37 percent of dry matter is in the range of 2.5 percent to 3.71 percent. Observing this, it can be said that the results of the study show very high levels of crude fat, while according to [13]. in general, the crude fat content of Setaria splendida Stapf is in the range of under 2 percent. But the research results of about liquid organic fertilizer also showed high levels of 2.18 percent. Observing the two studies, it is suspected that there was a contribution from the use of liquid organic fertilizer, especially traditional market waste $[2,9]$.

[Table 2] also shows that the older the Setaria splendida Stapf grass produces a higher average fat content, which is between 3.25 percent and 3.54 percent. In the application of liquid organic fertilizer, 
showing the addition of dilution has reduced levels of crude fat. The low nutrient content of liquid organic fertilizer according to Ilieva end Vasileva (2013) will affect the quality of forage produced from feed plants. Although each treatment produced different conditions, the results of the analysis showed no effect of the treatment on the analysis of crude fat content of Setaria splendida Stapf grass. These conditions show that the age of harvest to be applied and the dose of liquid organic fertilizer from traditional market waste become more open, but the results can be used as consideration in the preparation of rations related to crude fat content at the level of livestock needs [7]. state that liquid organic fertilizers which have more complexity in their nutrient content can influence the application of growth, production and quality of forage, however, the elemental content is relatively lower than the inorganic fertilizers that have been determined $[3,26,33,34]$.

Effect of Harvest Age and Dose of Traditional Market Liquid Organic Fertilizers on Crude Fiber Levels Setaria splendida Stapf

Older defoliation age from Setaria splendida Stapf up to 45 days showed a higher crude fiber content of 32.14 percent, while the dose of liquid organic fertilizer was getting thinner and higher even though it was not conspicuous, while the average treatment obtained crude fiber content of 30.92 percent. This condition is lower than Jank, et al., (2007) which states that in various conditions the content of crude fiber Setaria splendida Stapf is 31.75 percent. It is possible that the low nutrient content of liquid organic fertilizer also results in low levels of crude fiber of grass [27,30].

The results of the analysis of variance showed that the treatment given had no effect $(\mathrm{P}>0.05)$ on the levels of crude fiber Setaria splendida Stapf. The treatment of harvest age and the dose of liquid organic fertilizer can be used to obtain the desired levels of crude fiber. Crude fiber from forage is important to know in the preparation of feed ingredients [32]. The treatment that produces the highest levels of crude fiber is the grass harvested at 45 days by applying liquid fertilizer of traditional market organic waste at a ratio of 1: 3 which is 32.68 percent of the dry matter content. However, basically the older age of crude fiber harvest the higher the levels, while the desired levels of crude fiber from forage as feed material is not too high so as not to interfere in the physiological processes of animal digestion [5,12]. Consideration on the dose of liquid organic fertilizer will be prioritized in obtaining expected results [1] .In general it can be seen that the higher dose of water mixing in liquid organic fertilizer causes the nutrient content of fertilizer to be lower [3]. Reduction of nutrient levels due to dilution of liquid organic fertilizer results in a decrease in plant growth [35].

Associated with the traditional market organic waste that is abundant in cities, is a source of pollutants, but on the other hand can be seen as abundant natural resources that can be used for human life. Various efforts include composting, but can also be used through liquid fertilizer in crop cultivation including feed crops so that traditional market organic waste also has economic value to support human life.

\section{Conclusion}

The conclusion that can be obtained based on the description above shows that Setaria splendida Stapf grass plants show more production at the age of harvest up to 45 days with the use of a dose of traditional market liquid organic fertilizer mixed with water at a ratio of 1: 1 to produce good quality nutrients support the development of ruminants[1-36].

\section{References}

1. Sabrina DT, MM Hanafi, AW Gandahi, MTM Muhamed, NAA Aziz (2013) Effect of Mixed Organic-Inorganic Fertilizer on Growth and Phosphorus Uptake of Setaria Grass (Setaria splendida). Australian Journal of Crop Science 7: 75-83.

2. Hendarto E. Muslihudin, NL Rahayu, YA Romadhon (2018) Influence Of Liquid Organic Fertilizer On The Production And Carying Capacity Of Livestock From Setaria Grass (Setaria splendida stapf). International Conference on Energy, Environment and Information System (ICENIS). School of Postgraduate Studies Diponegoro University. Proseding.

3. Madauna IS (2009) Study of Low Dosage of Complete Liquid Organic Fertilizer Effect on Weeds Growth and Corn Yield Applied in No Tillage Agriculture. Journal Agroland 16: 24 -32.

4. Ilieva A, V Vasileva (2013) Effect of Liquid Organic Humate Fertilizer Humustim on Chemical Composition of Spring Forage Pea. Banat's Journal of Biotechnology 4: 74-78.

5. Fitriana PR, Hidayat, T Akbarillah (2017) Nutrient Quality of Setaria spacellata harvested based on cutting intervals. Indonesian Animal Science Journal 12: 444 - 453.

6. Piri I, A Tavassoli (2012) Determining The Best Management of Nitrogen Fertilizer Consumption and Harvest Time of Forage Yield of Pearl Millet (Pennisetum glacum) in Shirvan Region. African Journal of Microbiology Research 6 : 2287-2293.

7. Bhilave MP, SB Nadaf, SV Bhosale, VB Nalawede (2013) Nutrition Analysis Of Plant Formulated Feeds. Research Journal of Agricultural Sciences 4: 480-483.

8. Xiangyang L, R Guangxi, S Yan (2011) The Effect of Organic Manure And Chemical Fertilizer on Growth and Development of Stevia Rebaudiana Bertoni. Energy Procedia 5: 1200-1204.

9. Hendarto E (2011) Dimensions of the Spatial Environment of Dairy Farms in Banyumas Regency. Dissertation. Diponegoro University Postgraduate Program. Semarang.

10. 10. Wijitphan S, P Lorwilai, C Arkaseang (2009) Effects of Cutting Heights on Productivity and Quality of King Grass (Pennisetum purpureum cv King Grass) Under Intensive Management of Nitrogen Fertilizer and Irrigation. Pakistan Journal of Nutrition 8: 1244-1250.

11. Wijitphan S, P Lorwilai, C Arkaseang (2009) Effects of Plant Spacing on Yields nd Nutritive values of napier Grass (Pennisetum purpureum Schum.) Under Intensive Management of Nitrogen Fertilizer and Irrigation. Pakistan Journal of Nutrition 8:1240-1243.

12. Greatheat H (2003) Plants And Plant Extracts For Improving Animal Productivity. Proceedings of the nutrition Society 62: 279-290.

13. Kindomihou MV, A Saidou, BA Sinsin (2014) Response to Fertilizer of Native Grasses (Pennisetum polystachion and Setaria sphacelata) and Legume (Tephrosia pedicellata) of Savannah in Sudanian Benin. Agriculture, Forestry and Fisheries 3: 142 -146.

14. Santana JAA, Daher RF, Ponciano NJ, Santos MMP, Viana AP, et al. (2018) Nitrogen and Phosphate Fertilizers in Elephant Grass for Energy Use. African Journal of Agricultural Research 13: 806-813.

15. Rahman MM, M Tateyama, M Niimi, RB Abdullah, WE Wan Khadijah, et al. (2013) Changes in Oxalate and Some Mineral Concentrations of Setaria sphacelata Under Cutting and Uncutting Conditions. Pakistan Journal of Biological Sciences.

16. Hendarto E dan Suwarno (2017) The Application of Liquid Fertilizer Made of Traditional Market Organic Wastes on 
Growth of Setaria Grass (Setaria splendida stapf). International Conference on Energy, Environment and Information System (ICENIS). School of Postgraduate Studies Diponegoro University. Proseding.

17. Jank L, KH Quesenberry, LE Sollenberger, DS Wofford, PM Lyrene (2007) Selection Of Morphological Traits To Improve Forage Characteristics of Setaria sphacelata Grow in Florida. New Zealand Journal of Agricultural Research 50: 73-83.

18. Okaraonye CC, JC Ikewuchi (2009) Nutrition and Antinutrition of Pennisetum purpureum (Schumach). Pakistan Journal of Nutrition 8: 32-34.

19. Wen L, SK Dong, YY Li, C Pulver, XY Li, et al. (2013) Variation of Botanical Composition, Forage Production and Nutrient Values along a Grassland Degradation Gradient in The Alpine Region of Qinghai-Tibet Plateau. International Journal of Experimental Botany 82: 45-54.

20. 20. Paskalis T, BB Koten, R Wea, JS Oematan, B Ndoen (2016) Growth and Forage Production of Setaria Grass (Setaria sphacelata) at Different Level of Liquid Organic Fertilizer Made of Pig Manure. Journal Animal Science 16: 22-27.

21. Sarwanto D, CH Prayitno (2015) The Diversity and Productivity of Indigenous Forage in Former Limestone Mining Quarry in Karst Mountain of Southern Gombong, Central Java, Indonesia. Animal Production, Scientific Journal of Farm Animals and Feed Resources in Tropic 17: 69-75.

22. Indriani NP, Y Yuwariah, A Rochana, H Djuned (2015) Effect of Intercropping Between Corn (Zea mays) and peanut (Arachis hypogaea) with Arbuscular Mycorrhizal Fungi (AMF) on the Yield and Forages mineral content. Pakistan Journal of Nutrition 4: 362-365.

23. Guenni O, S Seiter, R Figueroa (2008) Growth Respons Of Three Brachiaria Species To Light Intensity And Nitrogen Supply. Tropical Grasslands $42: 75-87$

24. Soro D, K Ayolie, FGB Zro, FY Yeboua, HK Kouadio, et al. (2015) Impact of Organic Fertilization on Maize (Zea mays L.) Production in a Ferralitic Soil of Centre - West Cote Divoire. Journal of Experimental Biology and Agricultural Sciences 3: 556-565.

25. Hendarto E, Bahrun, N Hidayat (2019) The Effect Of The Levels Of Liquid Organic Fertilizer From Traditional-Market Waste On The Production And Nutrient Contents Of Setaria Grass. International Conference on Animal Inovation on Tropic (ICAIT). Faculty of Animal Science, Jenderal Soedirman University. Proseding.

26. Onyeonagu, CC and Ugwuanyi (2012) Influence of Cutting Height and Nitrogen Fertilization on Plant Height and Tiller Production of Guinea Grass (Panicum maximum Jacq) Pasture. African Journal of Agricultural Research 7: 6401-6407.

27. Jan K, AM Rather, MV Boswal, AH Ganie (2014) Effect of Biofertilizer and Organic Fertilizer on Morpho-physiological Parameters Associated with Grain Yield with Emphasis for Further Improvement in Wheat Yield Production (Bread Wheat $=$ Triticumaestivum L). International Journal of Agriculture and Crop Sciences 7: 178-184.

28. Martens SD, Tiemann TT, Bindelle J, Peters M, Lascano CE (2012) Alternative Plant Protein Sources for Pig and Chickens in The Tropics - Nutritional Value and Constraints: A Review. Journal of Agriculture and Rural Development in Tropics and Subtropics 113: $101-123$

29. Ramakrishnan P, C Babu, K Iyanar (2016) Principal Component Analysis for Evaluation of Guinea Grass (Panicum maximum
Jacq.) Germplasm Accessions. International Journal of Environmental and Agriculture Research 2: 142-146.

30. Johnson CR, Reiling BA, Mislevy P, Hall MB (2001) Effcts of Nitrogen Fertilization and Harvest Date On Yield, Digestibility, Fiber and Protein Fractions of Tropical Grasses. Journal Animal Science 79: 2439-2448.

31. Tudsri, S., S.T. Jorgensen, P. Riddach and A. Pookpakdi, 2002. Effect of Cutting Height and Dry Season Closing Date on Yield and Quality of Five Napier Grass Cultivars in Thailand. Tropical Grasslands. Vol. 36: 248 - 252.

32. 32. Shahraki E, Saravani M (2013) A Study on the Effects of Urea and Molasses on the Nutrition Value of Nut Grass (Cyperus rotundus) Forage Silos of Sistan Region. International Research Journal of Applied and Basic Sciences 6: 1793-1800.

33. Novo AAC, RF Daher, GA Gravina, ES Costa, J Ogliari, et al. (2016) Effect of Nitrogen and Potassium Fertilization on Morpho-Agronomic Traits of Three Elephant Grass (Pennisetum purpureum Schum) Genotypes for Biomass Production. African Journal of Biotechnology 15: 2411-2423.

34. Mahdi SS, GI Hassan, SA Samoon, HA Rather, SA Dar, et al. (2010) Bio-Fertilizers in Organic Agriculture. Journal of Phytologi 2: 42-54.

35. Karyono T, Maksudi dan Yatno (2017) Mol Banana Weevil Bio Activator Addition and EM4 in a Mixture of Cattle Feces and Coffee Hush on Quality of Compost and Its First Harvers in Setaria (Setaria splendida Stapf). . Indonesian Animal Science Journal 12: 102-111.

36. Jigme N Jayamangkala, P Sutigoolabud, J Inthasan, S Sakhonwasee (2015) The Effect of Organic Fertilizers on Growth and Yield of Broccoli (Brassica oleracea L. var italic Plenckcv Top Green). Journal of Organic Systems 10: 9-14.

Copyright: (C2020 Eko Hendarto. This is an open-access article distributed under the terms of the Creative Commons Attribution License, which permits unrestricted use, distribution, and reproduction in any medium, provided the original author and source are credited. 